Article

\title{
Climate Change Effect on Building Performance: A Case Study in New York
}

\author{
Kristian Fabbri $\left.{ }^{1} * \mathbb{(}\right)$, Jacopo Gaspari ${ }^{1}\left[\right.$ and Licia Felicioni ${ }^{2}(\mathbb{C}$ \\ 1 Department of Architecture, University of Bologna, Sede di Cesena, 47521 Cesena (FC), Italy; \\ jacopo.gaspari@unibo.it \\ 2 University Centre for Energy Efficient Buildings, Czech Technical University, 27343 Prague, Buštěhrad, \\ Czechia Republic; licia.felicioni@cvut.cz \\ * Correspondence: kristian.fabbri@unibo.it
}

Received: 18 May 2020; Accepted: 16 June 2020; Published: 18 June 2020

\begin{abstract}
The evidences of the influence of climate change (CC) in most of the key sectors of human activities are frequently reported by the news and media with increasing concern. The building sector, and particularly energy use in the residential sector, represents a crucial field of investigation as demonstrated by specific scientific literature. The paper reports a study on building energy consumption and the related effect on indoor thermal comfort considering the impacts of the Intergovernmental Panel on Climate Change (IPCC) 2018 report about temperature increase projection. The research includes a case study in New York City, assuming three different scenarios. The outcomes evidence a decrease in energy demand for heating and an increase in energy demand for cooling, with a relevant shift due to the summer period temperature variations. The challenge of the last decades for sustainable design was to increase insulation for improving thermal behavior, highly reducing the energy demand during winter time, however, the projections over the next decades suggest that the summer regime will represent a future and major challenge in order to reduce overheating and ensure comfortable (or at least acceptable) living conditions inside buildings. The growing request of energy for cooling is generating increasing pressure on the supply system with peaks in the case of extreme events that lead to the grid collapse and to massive blackouts in several cities. This is usually tackled by strengthening the energy infrastructure, however, the users' behavior and lifestyle will strongly influence the system capacity in stress conditions. This study focuses on the understanding of these phenomena and particularly on the relevance of the users' perception of indoor comfort, assuming the IPCC projections as the basis for a future scenario.
\end{abstract}

Keywords: climate change; building energy performance; IPCC; thermal comfort; building energy consumption; +1.5 degree; cooling increase

\section{Introduction Concerning the Impacts of Climate Change}

Since 1970, a significant increase in the global mean temperature and atmospheric carbon concentration has been registered, however, the relation with climate change was assumed as a global challenge quite recently. Despite many evidences of the interdependency of phenomena, the conventional approach to cope with climate change impacts is often locally tailored rather than considered in the global dimension. Climate change is much less relevant to the human condition than warming in cities [1] and it can strongly influence both energy production/distribution and demand in the built environment [2] while increasing the risks that extreme events can heavily affect power infrastructures [3]. Adaptation and mitigation actions are therefore to be considered within a broader perspective that often goes beyond the local borders [4]. 
The Paris Agreement (December 2015) [5] represents indeed a step forward for the 1997 Kyoto Protocol and the quite limited commitment coming from some major countries. The massive improvement of renewable energy solutions (RES), required to achieve the defined ambitious goals, is clearly linked to the energy demand for heating and cooling with relation to indoor and outdoor comfort conditions which are clearly affected by climate change impacts [6]. In order to ensure acceptable comfort levels [7], a number of protocols, standards, and regulations have been developed with relation to the building sector. IPCC's 2018 reports about climate change (CC) and buildings can actually be considered one of the most authoritative documents to properly approach the topic. Additionally, some specific considerations are required to properly discuss the progress of European countries and the United States among the major nations involved in the climate change challenge in the West world.

\subsection{The 2018 IPCC's Report}

The periodic assessment of climate science by the Intergovernmental Panel on Climate Change (IPCC) since the early 1990s is an essential contribution to the achievement of a global ontology on climate change [8]. 2018 IPCC's report-“"Global warming of $1.5^{\circ} \mathrm{C}^{\prime \prime}$-is a key document within this challenge, offering a projection of the impact that a global warming of $1.5^{\circ} \mathrm{C}$ and the related global Greenhouse Gas emission (GHG emission) routes would produce compared to pre-industrial levels. The report highlights several impacts that could be avoided by limiting global warming to $1.5^{\circ} \mathrm{C}$ instead of $2{ }^{\circ} \mathrm{C}$ or more (such as sea level rise on a global scale by 2100 within a limit of $10 \mathrm{~cm}$, the decrease of coral reefs of $70-90 \%$ instead of $99 \%$, etc.). With the purpose of strengthening the global response to the threat of climate change, limiting global warming to $1.5^{\circ} \mathrm{C}$ requires rapid changes in so many aspects of society contributing to sustainable development and to eradicate poverty [9]. Two major issues are related to the built environment: the relation between the building and the city scale as well as their performances with reference to the energy demand.

\subsubsection{IPCC and the Role of Buildings and Cities}

IPCC establishes different approaches to consider climate change as a collective action problem, and among them, it turned into a story of global mean temperature foreclosing the range of possible response options. By translating the multi-layered problem-complex of climate change (climates multiple) into a unitary global problem (climate singular), IPCC paved the way for a single policy agenda: emissions control monitored through a UN coordinated policy regime [10]. Through the adoption of the 2015 Paris Agreement, the climate regime is today replaced by a more decentralized and isolated climate governance order. By inviting states to propose nationally-appropriate mitigation and adaptation responses, the Paris Agreement has distributed responsibility for climate action across multiple actors, arenas, and sites [11]. However, few methods are actually available to analyze implications of climate change on building energy use [12]. The understanding of the combination of different factors within the design and operation stages is still crucial in contributing to improve the performance level.

\subsubsection{Building Energy Performance (BEP)}

The building sector contributes up to $40 \%$ of global energy consumption $[13,14]$. Despite the efforts spent in the last decades to reduce emissions, the level of GHG in the different scenarios projections demonstrates a dramatic rise in the coming future [15]. In this context, buildings represent a critical piece of a low-carbon future and their response to climate change solicitations has to be reliably predicted in order to take effective strategic design decisions in the mid-term. The role of building simulation tools has increased in its importance, giving the chance to speed up the design process, increase efficiency, and compare a broader range of design options. Building performance simulation (BPS) has been a suitable tool for helping to reach solutions for better energy efficiency [16]. Simulation provides a better understanding of the consequences of design decisions, increasing the 
effectiveness of the whole system [17] and it is now becoming increasingly relevant in post-construction phases of the building life-cycle (BLC), such as commissioning and operational management and control. Software simulations allow to predict the system behavior within unobserved conditions, allowing analysts to simultaneously consider the impacts on the overall performance [18]. During the simulations, many different strategies are evaluated to obtain the higher performance for a set of objectives (e.g., zero energy balance) [19]. The energy performance of the buildings is really influenced by heat transmission, thermal mass, solar heat gain through windows; thus, any action in these fields can be of help in reducing building energy consumption [20].

\subsection{European Approach}

According to the IPCC Fifth Assessment Report (AR5), 32\% of global primary energy was spent by buildings, producing $19 \%$ of global emissions in 2010. Currently, these trends are still growing, reducing the chances to meet the targets agreed in the 2020 Climate and Energy Package [21], extended to 2030 [22] and 2050 within a long-term strategy [23,24]. The main efforts spent at the European Union (EU) level to reduce energy demand are addressed to decrease the needs for heating while ensuring adequate comfort conditions [25]. This led the EU to introduce the Energy Performance of Buildings Directive (EPBD Recast II [26] and EPBD Recast III [27]) and the Directive 2012/27/EU [28] on measures to help the EU to reach its 20\% energy efficiency target by 2020 [29]. Each Member State can acknowledge the directives according to the most suitable and effective conditions within its own context in order to meet the targets (nearly Zero Energy Building (nZEB)) and to become more resilient to future climate conditions [30]. However, the effects of climate change and the evolving weather variables are influencing this process, impacting both the local network development [31] and energy use. Following IPCC projections, the energy demand for heating decreases due to the temperature variations and to the building performance improvement, while the demand for cooling is growing due to the increase of cities mean temperature.

\subsection{USA Approach and New York Greening Actions}

The recent withdrawal of the United States from the Paris Agreement requires a reflection on the situation of one of the biggest contributors to global emissions, which is also a country severely affected by the often dramatic consequences of extreme events [32]. Commercial and residential buildings account for about $40 \%$ of the primary energy demand in the US and respectively $9.9 \%$ and $5.4 \%$ of global GHG emissions.

Despite the decision at the federal level, some states, such as New York and California, continue their actions against the climate change autonomously. In September 2018, Senate Bill 100 (SB100) required the Renewable Portfolio Standard (RPS) for electric utilities from $50 \%$ to $60 \%$ by 2030 and further targeted 100\% clean energy in all sectors by 2045 [33]. New York City has developed several scientific reports and local regulations for improving urban resilience to cope with climate change [34]. In 2018, the New York government recognized the urgency for renovating the energy network by providing micro-grids, to help the systems surviving natural disasters or energy demand peaks that recently brought to the grid collapse. Renewable energy is certainly part of these important environmental goals and the New York State energy plan of 2015 aims to shift from 11\% [35] to $40 \%$ of energy needs by 2030 . The "Reforming the Energy Vision" initiative $[36,37]$ integrates technical, management, and marketing approaches to explore the compatibility of small-scale renewable technology with existing residential buildings, commercial, or public areas, serving local needs while remaining connected to the wider network system.

\section{Projections of Annual Climate Change in New York}

After the dramatic events of Hurricane Sandy, the New York City Panel on Climate Change (NPCC [38]) developed a system to collect and update information on the climate risk for the city with the purpose to both address the recovery after the event and to improve the resiliency. 
The climate change impacts could be both short-term (storms and floods) and long-term (gradual changes in outdoor air temperature and sea level rise). As reported in NPPC [38], the long term impacts will be extremely likely events in the state of New York. Average annual temperatures are expected to increase up to $1.5^{\circ} \mathrm{C}\left(3^{\circ} \mathrm{F}\right)$ warmer by the $2020 \mathrm{~s}$, up to $3.3^{\circ} \mathrm{C}\left(6^{\circ} \mathrm{F}\right)$ warmer by the $2050 \mathrm{~s}$, and up to $5.5^{\circ} \mathrm{C}\left(10^{\circ} \mathrm{F}\right)$ warmer by the 2080s [38]. By 2100, the growing season could be about a month longer, with intense summers (extreme heat and heat waves) and milder winters. At the same time, rainfall will also increase noticeably, $1-8 \%$ by $2020,3-12 \%$ by 2050 , and $4-15 \%$ by 2080 . These changes are associated with an increase in greenhouse gases and global warming [39]. The frequencies of heat and frost waves, intense rainfall, droughts, and coastal floods in the seven regions of the state will be subject to change in the coming decades, as predicted by the global climate model. These gradual changes will bring several consequences on built environment, and its energy consumption. Due to the huge difference between the outdoor air temperature and indoor temperature, the cooling systems will be responsible for the potential increase of energy end-use consumption. This is the state of the art so far following the IPCC report scenarios.

For investigating the impact of climate change on building energy consumption, the use of building simulation software, together with a set of forecasted weather data, is essential [40]. Within this general context, the methodology framework reported in this paper focused on the effects of a renovation project involving an iconic 14-story residential building in Red Hook, Brooklyn, New York considering the IPCC climate future projections of $+1.5^{\circ} \mathrm{C}$ overheating. The impact of climate change on indoor thermal comfort in the residential sector under different scenarios was also evaluated and reported in this paper.

\section{Scope of the Research}

The paper reports the outcomes of research aimed to evaluate the implications of IPCC climate change projections in the construction sector, applied to a case study in New York City.

The scope is to translate the outcomes of the research activities into concrete and practical indications that might be of help in replicating and driving the design process to tackle the climate change issue. Energy demand for heating and cooling is analyzed considering three weather scenarios $(1958,2017,2100)$ according to IPCC projections and tested on a case study in Brooklyn, New York. In this way, simulations can take into account the predicted evolution of climate change [41]. The proposed study is primarily referred to the residential sector, which is the most relevant share in the building stock and one of the key targets of many regulations and governmental measures but can easily be adapted to other typologies. The paper aims also to provide a reflection on the effects of climate change to the thermal comfort, and the resistance of clothing (expressed in clo, $\mathrm{m}^{2} \mathrm{~K} / \mathrm{W}$ ) is used as a variable. The clothing resistance characteristics are expressed as an average value, i.e., they refer to all the clothing worn and not just some (e.g., only the shirt, etc.).

\section{Research Methodology}

The adopted methodology includes the calculation of Building Energy Performance Simulation (BEPS) for the case study considering three climatic scenarios. Weather data for the selected years are provided by Energyplus for 1958 and 2017-construction time and current condition respectivelywhile 2100 follows the IPCC temperature increase projection.

The use of weather data in simulation software like Energyplus, Ies.Ve, etc., can come from different sources (e.g., satellite data, weather stations, climate models, etc.) whose level of accuracy and reliability of the data source may change.

For the purposes of our research objectives, which is the evaluation of the variation over time of the simulation results, we considered the use of the data in the software database for the years 1958 and 2017. This choice may be questionable, but in this case, their accuracy supports the reliability of the adopted methodology. The approach combining simulations and scenarios is quite consolidated in 
the scientific literature, however, the focus on the effects of a temperature increase of $+1.5^{\circ} \mathrm{C}$ and the related overheating represent a novelty.

The research methodology is described following three sections:

1. BEPS of the state of the art (it provides the starting conditions of the case study);

2. Thermal comfort and clothes insulation;

3. Thermo-economic renovation scenarios of improving building energy performance.

Figure 1 provides a flowchart of the research methodology (that is specifically designed to facilitate the replication to other case studies).

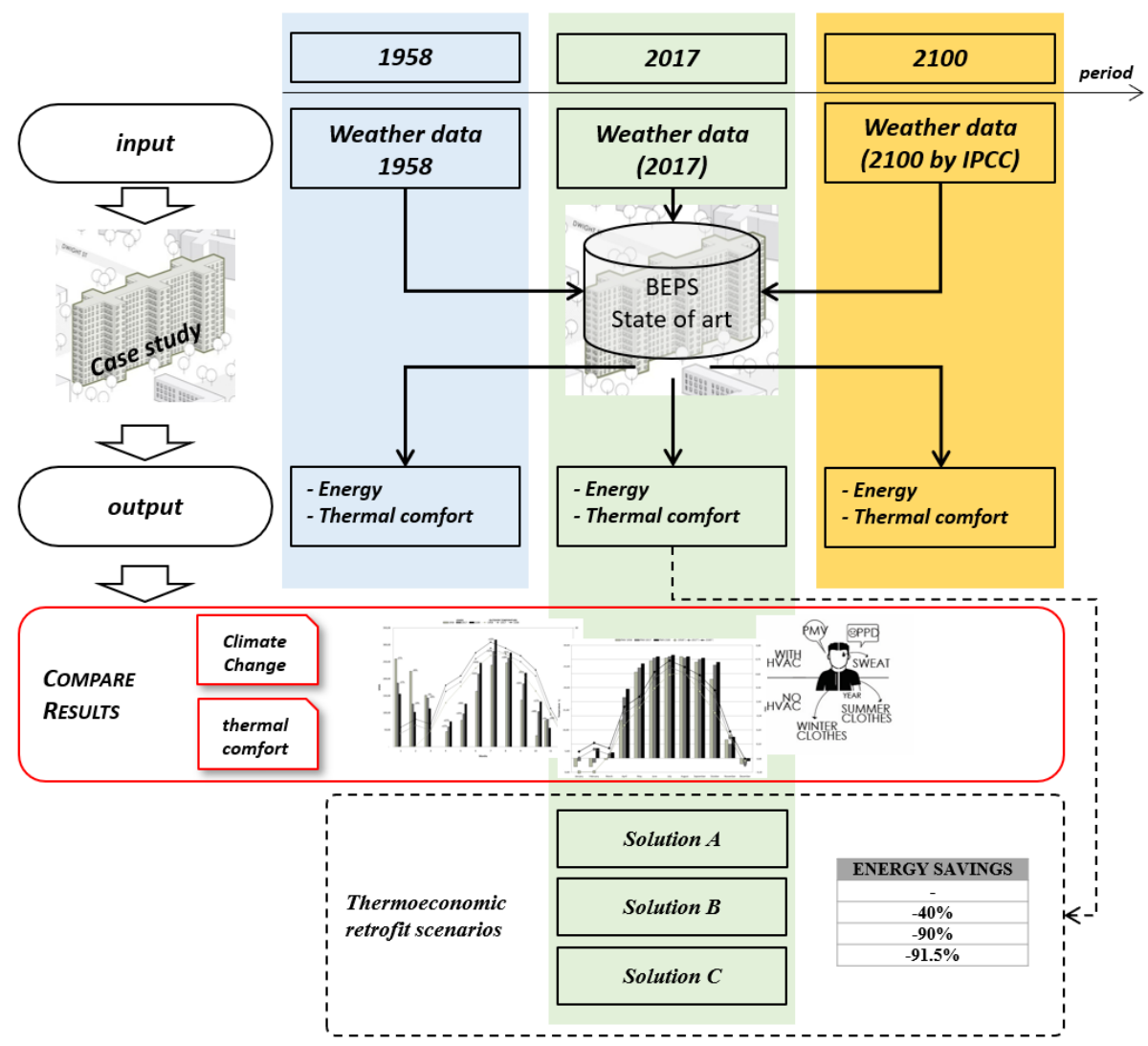

Figure 1. Flowchart of the research methodology.

The first phase of the process is to reach a stable configuration of the virtual model in order to assume the weather data as the key variable and then perform preliminary thermo-physical analyses to evaluate the thermal/energy behavior. With weather data being the key variable, it is possible to compare the different behavior and the energy consumption of the building in the three different scenarios investigating the effects of temperature increase and related impact.

A complete set of thermo-physical analysis is provided for each scenario (S1-1958, S2-2017, S3-2100). The set includes also coherent values concerning loads, energy consumption, and indoor comfort, which are useful indicators to evaluate the behavior of the building with reference to the summer conditions. The methodological approach can be easily adapted to any context and case study.

The investigated outputs include: (a) yearly energy need for heating and cooling $\left(\mathrm{kWh} / \mathrm{m}^{2}\right)$, (b) total electricity/natural gas (MWh) consumption, (c) total energy consumption, (d) indoor comfort evaluated considering the predicted mean vote (PMV) and the predicted percentage dissatisfied (PPD in percentage, \%) when the heating, ventilation, and air-conditioning (HVAC) system is operating, (e) indoor comfort evaluated considering the PMV and PPD when HVAC is not operating and consequently focusing on the clothing relevance. 
The geometry and configuration of the building were rendered using Integrated Environment Virtual Environment software (IES.VE [42]), as well as the energy simulation to investigate the potential impacts of temperature increase due to climate change.

\subsection{Weather Data for Each Scenario}

The research methodology requires three sets of weather data [43] corresponding to the three investigated scenarios (Sc.1 1958, Sc.2 2017, Sc.3 2100). The number 1958 refers to the closest period respect to the year when the building was erected (1939) and then entered in the decade of ordinary operation, 2017 refers to the present time conditions, 2100 refers to the IPCC projection horizon. Weather files referred to 1958 and 2017 were respectively downloaded from Energy Plus (Energy Plus, 2019) and World Meteorological Organization region and Country. Weather data format is a plain text file *.epw (EnergyPlus Weather) and the National Weather Service Forecast Office (National Weather Service, 2019) was used as a typical meteorological year (TMY) [44]. The third set (future projection) is generated based on the 2017 one, assuming an overheating of $1.5^{\circ} \mathrm{C}$ dry-bulb temperature, from 2018 to 2100, reported in the IPCC protocol [9], obtained using Element software. This is the main assumption of the entire article: analyze what happens if the IPCC forecasts on temperature are applied to the building performance simulation. Table 1 allows to compare the temperature increase over the years between the three sets. It can be observed that the 1958's winter temperatures were more rigid than the 2017's ones and this is a main effect of the increased temperatures as a consequence of climate change and the heat island effect because, within 60 years, the NYC's built environment has changed drastically.

Energy demand for heating and cooling was analyzed and compared for the three scenarios (climate models) [45,46]. The proposed methodology can be applied to different places simply by replacing the initial climate conditions (.epw) of the site under investigation.

Table 1. Average outdoor temperature.

\begin{tabular}{cccc}
\hline Year & $\mathbf{1 9 5 8}$ & $\mathbf{2 0 1 7}$ & $\mathbf{2 1 0 0}$ \\
\hline & Average Outdoor Temperature ${ }^{\circ} \mathbf{C}$ & Average Outdoor Temperature ${ }^{\circ} \mathbf{C}$ & Average Outdoor Temperature ${ }^{\circ} \mathbf{C}$ \\
\hline January & 0.06 & 3.39 & 4.89 \\
\hline February & 0.12 & 5.44 & 6.94 \\
\hline March & 3.97 & 4.18 & 5.68 \\
\hline April & 11.10 & 13.96 & 15.46 \\
\hline May & 15.27 & 16.36 & 17.86 \\
\hline June & 19.85 & 22.20 & 23.70 \\
\hline July & 23.03 & 24.88 & 26.38 \\
\hline August & 23.55 & 23.36 & 24.86 \\
\hline September & 19.11 & 21.45 & 22.95 \\
\hline October & 14.06 & 17.87 & 19.37 \\
\hline November & 8.55 & 8.13 & 9.63 \\
\hline December & 2.81 & 1.70 & 3.20 \\
\hline Average year & 11.79 & 13.57 & 15.07 \\
\hline & & $+1.8^{\circ} \mathrm{C}$ compared to 1958 & \\
\hline
\end{tabular}

\subsection{Limitation of the Methodology}

Research relating to climate change is focused on the effects of energy use, pollution, and environmental issues. The main objective of this paper is not to report the review of these studies, but to highlight the effects that it will have as a result of climate change both on the energy consumption of buildings (specifically for this case study) and for indoor comfort and, consequently, on the clothing insulation. Given the complexity of the research carried out, some methodological limits have been assumed to be able to extend and compare the results with other (future) research. The methodological limits concern: 
- The choice to consider the climate change effects only as an increase in the outdoor temperature of $1.5^{\circ} \mathrm{C}$;

- The choice to consider as a parameter for the evaluation of the indoor comfort the internal temperature, thus excluding the detailed analysis of other parameters such as the mean radiant temperature (MRT) or relative humidity (RH);

- The choice to consider clothing insulation as a variable that will suffer the effects of climate change; in this case, the variable adopted is the thermal resistance of the clothing $\left(I_{c l}\right)$ (expressed in clo, $\left.\mathrm{m}^{2} \mathrm{~K} / \mathrm{W}\right)$.

The unavailability of original consumption data did not allow the validation of the virtual model according to real conditions, however, a standardized calculation method has been adopted and the same approaches can be adopted in any other case study in a different context.

\subsection{BEPS of the State of the Art}

Energy simulations were performed using the Integrated Environment Virtual Environment software (IES.VE [42]).The building was modeled to fix the main geometrical features and shape, the boundary conditions, the heating and cooling systems, as well as the services and installations. The building was approximated to a volume 100 meters long, 10 meters wide, and 40 meters tall, corresponding to an affordable housing building hosting 300 apartments in its 14 stories. The study estimated the energy consumption in each scenario with the purpose to evaluate the impact of climate change on the entire building energy demand. The heating/cooling set-points are defined in $20^{\circ} \mathrm{C} / 27^{\circ} \mathrm{C}$, target temperatures within the range that is acceptable to 80 percent of the building occupants according to ANSI/ASHRAE Standard 55, Thermal Environmental Conditions for Human Occupancy. A virtual simulation model was created, and the outcomes of simulations were then compared. Simulations considered the thermal inputs given by internal gains. The same building model (geometry, thermophysics, internal gains, etc.) was used for the simulation purpose, but each simulation was associated to its own weather data file $(1958,2017,2100)$ of the set climatic zone: New York Central Park (*.fwt or *.epw file). The increase of temperature due to climate change influences the energy consumption of the building, leading to worsening of comfort conditions.

\subsection{Thermal Comfort and Clothes Insulation}

The reference model about thermal comfort is still the one developed by Fanger [47] that focuses on two indices: predicted mean vote $(P M V)$ and percentage people dissatisfied $(P P D)$, which respectively refer to occupants' mean thermal sensation vote and the percent of people voting. The PMV-PPD model is a widely used design tool incorporated in thermal comfort standards [48,49] that can be equally applied to different building typologies and climate conditions. Nevertheless, the accuracy of the PMV-PPD model in predicting thermal comfort has been questioned through field studies in real buildings [50] as well as in laboratory studies [51].

With this reference, the reported study focused on the relevance of occupants' clothing with relation to their thermal sensations inside the building. Statistical analyses were performed with the aim to better understand how building occupants can achieve thermal comfort by adjusting their clothing level of insulation [52]. This is quite relevant, assuming the poor insulation characteristics of the building envelope and the low-income condition of most of the residents which limit the opportunity to reach adequate comfort levels.

The proposed neutral clothing model can be used to determine whether clothing adjustment can sufficiently offset indoor temperatures in naturally ventilated building contexts [53]. The driving question was therefore: which clothing allows to perceive a good comfort condition comparable to a $P M V=0$ (neutral) in the scenario without HVAC? To provide an answer for each scenario $(1958,2017$, 2010) $P M V$ was imposed $=0$ and the calculation was repeated by setting different clothing insulation values $I_{c l}(\mathrm{clo})$. 
The HVAC system was turned off in order to create a neutral condition, otherwise the system operates to achieve satisfactory comfort conditions.

Clothing insulation $\left(I_{c l}\right)$ is an input variable for thermal comfort calculations, and appropriate clothing adjustment can widen the comfort range and reduce building energy consumption [54]. For people in sedentary activities (a metabolic rate of approximately $1.2 \mathrm{met}$ ), the effect of changing clothing insulation on the optimum operative temperature is approximately $6{ }^{\circ} \mathrm{C}$ per clo, which is much relevant.

\subsection{Thermo-Economic Retrofitting Solutions for Improving the Building Energy Performance}

The thermo-economic analysis combines thermo-physical analysis with economic aspects to identify factors involved in the generation of energy costs. Highest inefficiencies and costs are related to the processes in which natural gas is burned, hence in the boilers. The presented analysis can be extended to other energy systems. The trend for the following years shows a continuous increase in world population, $\mathrm{CO}_{2}$ emissions, and primary energy consumption. For that reason, in the building environment, the design of efficient systems has become a primary objective for energy policies in most countries [55]. The starting assumption of the study is that the investigated solutions are expected to let the building reaches a lower consumption, according to the major rating systems, meaning a consumption not exceeding $15-20 \mathrm{kWh} / \mathrm{m}^{2}$ on an annual basis and the fulfilment of a number of sustainable indicators. Such conditions are achieved through a combination of different design choices involving several parameters, which are not all under investigation, in a balanced contribution deriving from the building envelope characteristics and services/installations.

For the case study under investigation, three main retrofit solutions were considered.

Retrofit A solution envisages the replacement of windows, respecting the U-values thresholds, and adding an insulation layer in the inner side of the wall to maintain the original exposed brick facing of the building.

Retrofit B solution replaces the original natural gas installation for heating and the single units for cooling with an electric heat pump and adding a controlled mechanic ventilation in each blind space.

Retrofit $\mathrm{C}$ solution adds to the measures included in $\mathrm{A}$ and $\mathrm{B}$ solutions, the renovation of the apartments following the guidelines of New York City HPD (Housing Preservation and Development) Department.

The set includes also coherent values concerning energy consumption for cooling and heating, which are useful indicators to evaluate the change of building energy performance due to the renovation process. A first observation of the outcomes, gives the chance to considerer how relevant the installations replacement may be in terms of energy performance. The main goal is not simply to compare the energy consumption of each scenario $(\mathrm{A}, \mathrm{B}, \mathrm{C})$, that would of course reflect the differences due to the renovation intensity, but to address reflections towards the relation between them and the building energy performance as a relevant concern to be properly taken into account during the retrofitting phase for reducing energetic costs of the entire building and following a more sustainable approach.

\section{Case Study Description}

The case study is part of a social housing development in Brooklyn (NYC) (Figure 2), known as "Red Hook Houses", owned by the New York City Housing Authority (NYCHA), the major social housing developer of North America, who since 1934, provides affordable and qualitatively sufficient housing for the low-income population of New York. Since 1939, when it was erected, the buildings were never heavily renovated and only after 2012 Hurricane Sandy, some extraordinary maintenance activities were done to install new utility systems due to the flooding event. The reference building (Figure 3) is 14 stories tall and was constructed using a reinforced concrete frame system with an exposed brick cladding. The building counts 300 apartments respecting the minimum air-illuminating ratio.

New York City has a humid continental climate with mean annual precipitation of $127 \mathrm{~mm}$ (50 inch) [56]. The 2017 mean annual temperature was $13.58^{\circ} \mathrm{C}$, with $24.88^{\circ} \mathrm{C}$ in July and $1.70{ }^{\circ} \mathrm{C}$ in 
December, the hottest and coldest months, respectively. The simulation settings were the same in all the three scenarios: each building model had the same internal footprint, window size and glazing properties, the same HVAC system, internal gains, and infiltration rates, as Table 2 summarizes.

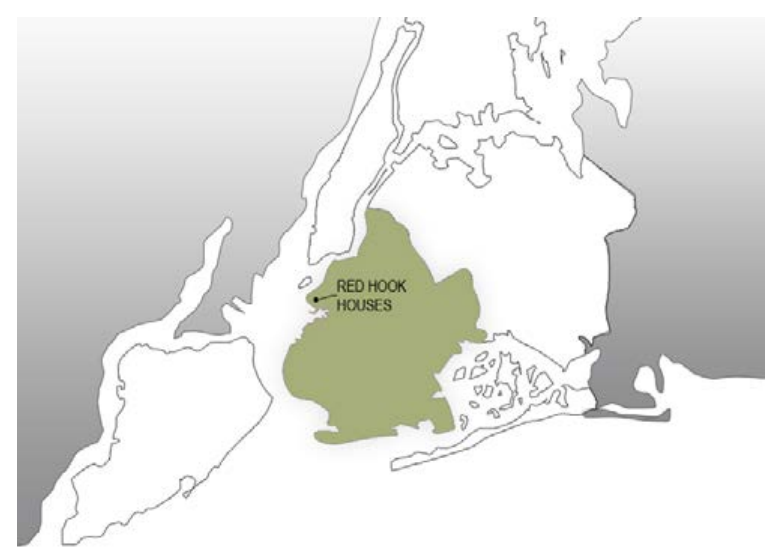

Figure 2. New York City-Red Hook Houses in Brooklyn.

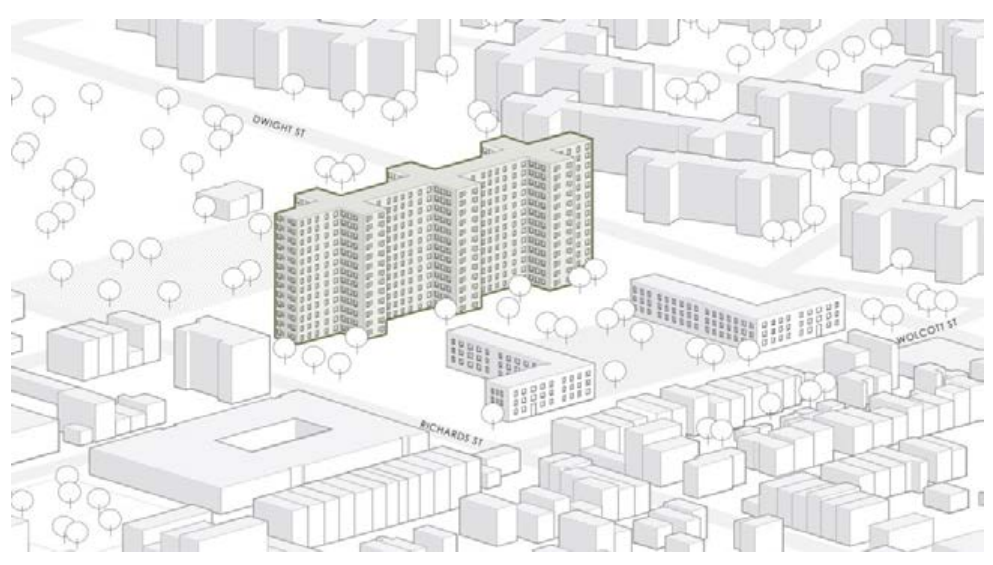

Figure 3. Zoom on investigated building.

Table 2. Building model details.

\begin{tabular}{cc}
\hline Building Model Details & Data \\
\hline Floor Area & $1600 \mathrm{~m}^{2} \times 14$ stories $=22,400 \mathrm{~m}^{2}$ \\
\hline Orientation & Principal axis running northwest-southeast direction \\
\hline Windows & One glazed window $(1.6 \times 1.6 \mathrm{~m}-1.6 \times 1.2 \mathrm{~m}-1 \times 1.6 \mathrm{~m}-0.5 \times 1.6 \mathrm{~m})$ \\
\hline U-Value & Walls $=0.16392$ \\
\hline U-Values $\left(\mathrm{W} / \mathrm{m}^{2} \mathrm{~K}\right)$ & Floor $=0.15853$ \\
\hline & Ceiling $=0.10866$ \\
\hline HVAC system & Ideal loads \\
\hline HVAC Set points & $20^{\circ}$ Heating/27 Cooling \\
\hline HVAC Schedule & $24 \mathrm{~h}($ Continuously on $)$ \\
\hline Internal Gains & Fluorescent Lighting \\
\hline Infiltration & People $($ max 90 W/person-min $60 \mathrm{~W} /$ person $)$ \\
\hline
\end{tabular}




\section{Results}

The results of the study are about three different aspects:

1. BEP of different scenarios (1958, 2017, and 2100);

2. Thermal comfort in different scenarios $(1958,2017$, and 2100);

3. Thermo-economics evaluations after retrofitting for improving building energy performance.

\subsection{BEP Results for Scenarios of Climate Change (1958, 2017, and 2100)}

Indoor temperature is one of the parameters used to assess people's health and their comfort level. With the HVAC turned on, the average internal temperature is in a range of $20^{\circ} \mathrm{C}-27^{\circ} \mathrm{C}$ all year; when HVAC is tuned off, the temperature varies from minimum peaks of $3^{\circ} \mathrm{C}-4^{\circ} \mathrm{C}$, up to maximums of about $30^{\circ} \mathrm{C}$.

\section{a. Heating and cooling energy need loads}

Figure 4 shows the room heating/cooling loads of all scenarios. In the first scenario (1958), the need for heating during the winter months is greater than the other two $(2017,2100)$, since the average outdoor temperature is lower.

Instead, in summer, the demand for cooling in 1958 was less than the one in 2017 and the one expected in 2100. Compared to 2017, the projection for the summer period always increases while consumption is much higher for heating. Figure 4 shows the relation between energy loads for heating and cooling, by month, compared with outdoor temperature, for each scenario year: 1958, 2017, and 2010. As we can observe, cooling load increase in the 2100 scenario following outdoor temperature, if we compare 1958 and 2100 scenarios, we observe a swift of energy loads from winter (250 MWh heating load in 1958) to summer (320 MWh cooling load in 2100), which is depending on climate change.

\section{b. Energy}

Table 3 shows the increase of cooling load despite the decrease of heating loads in all scenarios due to the climate change. Despite this switch, the total amount of consumption remains unchanged. Moreover, Table 3 shows the relation between electricity and fuel use: increasing the temperature, the demand for electricity is higher, while the request for natural gas decreases.

Table 3. Annual average energetic loads (MWh/year).

\begin{tabular}{cccc}
\hline Energy Data & $\mathbf{1 9 5 8}$ & $\mathbf{2 0 1 7}$ & $\mathbf{2 1 0 0}$ \\
\hline Heating loads & 2220 & 1825 & 1475 \\
\hline Cooling loads & 1425 & 1825 & 2150 \\
\hline Total energy loads & 3645 & 3650 & 3625 \\
\hline Energy consumption & & & \\
\hline electricity & 790 & 835 & 875 \\
\hline natural gas & 185 & 150 & 120 \\
\hline Primary energy & 975 & 985 & 995 \\
\hline
\end{tabular}




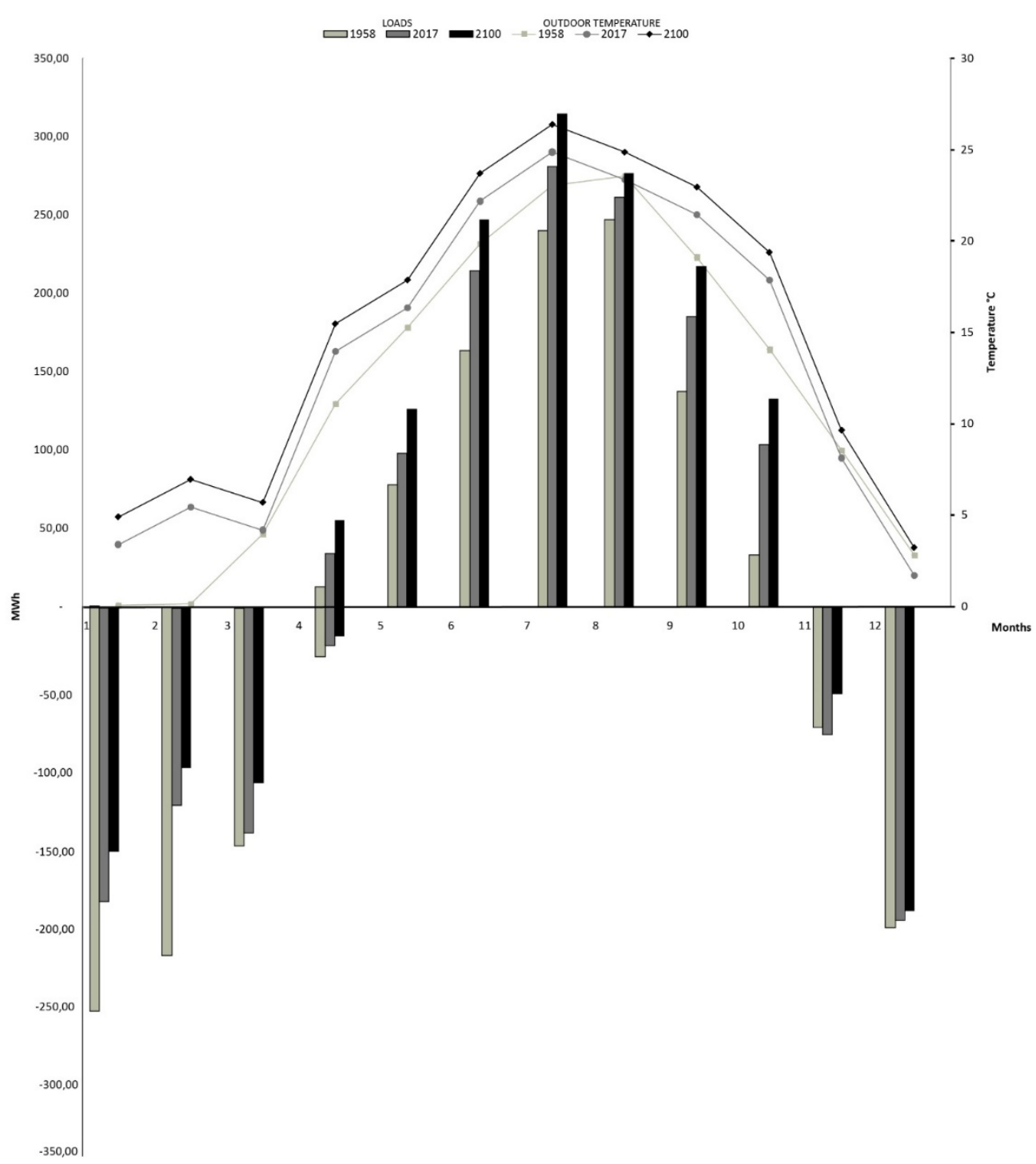

Figure 4. Building energy loads, for heating and cooling, compared to outdoor temperature $\left({ }^{\circ} \mathrm{C}\right)$ in free running.

\subsection{Thermal Comfort in the Different Scenarios}

The existing clothing models are typically used to estimate a clo-value of a group of building occupants, which then becomes input data for PMV calculations following ISO 7730 [48] and ASHRAE 55 [49]. $P M V$-predicted percentage dissatisfied model, thermal neutrality $(P M V=0)$ is deemed as an ideal or optimal status where the number of 'dissatisfied' building occupants is minimum.

\section{a. Indoor Comfort WITHOUT HVAC system}

The effect of climate change without HVAC on indoor comfort perceived by users is also investigated. Table 4 shows the PMV values (predicted mean vote) of the users when the HVAC system is OFF, correlated to the average external temperature. The results evidence higher value of $P M V$, from -3 (cold) to 3 (hot), meaning that people are dissatisfied. The results prove that installations/services play a very relevant role in users comfort perception; more than $90 \%$ of people are dissatisfied during summer. 
Table 4. PMV-without HVAC system related to the average outdoor temperature $\left({ }^{\circ} \mathrm{C}\right)$.

\begin{tabular}{ccccccc}
\hline Month & $\mathbf{1 9 5 8}{ }^{\circ} \mathbf{C}$ & PMV 1958 & $\mathbf{2 0 1 7}{ }^{\circ} \mathbf{C}$ & PMV 2017 & $\mathbf{2 1 0 0}^{\circ} \mathbf{C}$ & PMV 2100 \\
\hline January & 0.06 & -2.35 & 3.39 & -1.82 & 4.89 & -1.52 \\
\hline February & 0.12 & -2.13 & 5.44 & -1.33 & 6.94 & -1.02 \\
\hline March & 3.97 & -1.43 & 4.18 & -1.16 & 5.68 & -0.84 \\
\hline April & 11.10 & -0.08 & 13.96 & 0.49 & 15.46 & 0.79 \\
\hline May & 15.27 & 1.26 & 16.36 & 1.51 & 17.86 & 1.81 \\
\hline June & 19.85 & 2.12 & 22.20 & 2.49 & 23.70 & 2.66 \\
\hline July & 23.03 & 2.79 & 24.88 & 3.00 & 26.38 & 3.00 \\
\hline August & 23.55 & 2.89 & 23.36 & 2.92 & 24.86 & 3.00 \\
\hline September & 19.11 & 2.28 & 21.45 & 2.57 & 22.95 & 2.82 \\
\hline October & 14.06 & 1.01 & 17.87 & 1.87 & 19.37 & 2.18 \\
\hline November & 8.55 & -0.28 & 8.13 & -0.34 & 9.63 & -0.03 \\
\hline December & 2.81 & $\mathbf{- 1 . 5 9}$ & 1.70 & -1.64 & 3.20 & -1.33 \\
\hline Annual average & $\mathbf{1 1 . 7 9}$ & $\mathbf{+ 0 . 3 7}$ & $\mathbf{1 3 . 5 8}$ & $\mathbf{+ 0 . 7 1}$ & $\mathbf{1 5 . 0 8}$ & $\mathbf{+ 0 . 9 6}$ \\
\hline Winter average (Oct-Mar) & $\mathbf{4 . 9 3}$ & $\mathbf{- 1 . 1 3}$ & $\mathbf{6 . 7 9}$ & $\mathbf{- 0 . 7 4}$ & $\mathbf{8 . 2 9}$ & $\mathbf{- 0 . 4 3}$ \\
\hline Summer average (Apr-Sep) & $\mathbf{1 8 . 6 5}$ & $\mathbf{+ 1 . 8 8}$ & $\mathbf{2 0 . 3 7}$ & $\mathbf{+ 2 . 1 6}$ & $\mathbf{2 1 . 8 7}$ & $\mathbf{+ 2 . 3 5}$ \\
\hline
\end{tabular}

We can observe in Table 4 the annual average value of thermal comfort index PMV increase from +0.37 (as "neutral" or "slightly warm" sensation) of 1958 to 0.96 ("slightly warm" nearly "warm" sensation) of 2100 , this is a huge difference.

In detail, during the winter season, from October to March, index PMV change from - 1.13 ("cool" sensation) in 1958 , to -0.43 (slightly cool) in 2010 , so we suppose a less energy need to heat in the 2100 scenario. During the summer season, from April to September, the index PMV change from +1.88 ("warm" nearly hot sensation) to +2.35 corresponds with a very hot sensation, nearly a heat stress value.

These simulations are without HVAC systems, so the sensation depends only by building, so it is evidenced by the main role of heating and cooling equipment and their energy consumption to guarantee a neutral thermal comfort sensation (neutral if PMV equal to zero). Following the above approach, not only does HVAC have a role, but also clothes in indoor, described in the next paragraph, we would like to discover which dress people put on their body to feel a neutral thermal comfort, when the $P M V$ index is equal to zero.

\section{b. Relevance of clothing}

For ensuring good comfort condition comparable to a $P M V=0$ (neutral) and metabolic activity is equal to 1 met (seated activity) in no operating HVAC scenario, a PMV $=0$ was imposed and the calculation was iterated with different $I_{c l}$ (clo) (clothing resistance) for each case. Table 5 provides a summary of the outcomes where it is clearly evident that during the summer period, comfort is acceptable only wearing shorts and a t-shirt (the perception is the one of a clearly overheated environment), while during winter, a polar equipment would be needed to achieve minimum livable conditions.

The adopted approach intentionally stresses the focus on the role of clothing and on the perception of users to remark the dependency of comfort conditions from HVAC and generally from services and installations. This is strictly connected to the inefficient and low performing condition of the building envelope which - at the stating conditions - is highly inadequate to meet the energy demand reduction that is expected in the very near future.

In Table 5, it is possible to observe the annual average value of clothes (or dress thermal resistance) to guarantee a neutral thermal comfort $(P M V=0)$ that corresponds to 2.01 clo (Underwear with short sleeves and legs, shirt, trousers, jacket, heavy quilted outer jacket and overalls, socks, shoes, cap, and gloves, following ISO 9920 Annex A [57]) in 1958 and 1.58 clo (Underwear with short sleeves and legs, shirt, trousers, vest, jacket, coat, socks, and shoes, following ISO 9920 Annex A) in 2100, with a decrease of 0.40 clo of clothes thermal resistance, which corresponds to a sweater or jacket. In detail, during the winter season, from October to March, clothes thermal resistance $\left(I_{c l}\right)$ change from 3.22 to 
2.67 clo with a gap of 0.55 clo, while in the summer season, from April to September, the gap is 0.30 clo, which corresponds to a t-shirt.

Table 5. Clothes insulation (measured in clo) without HVAC and $P M V=0$, related to average indoor temperature.

\begin{tabular}{ccccccc}
\hline Without HVAC & $\mathbf{1 9 5 8}{ }^{\circ} \mathbf{C}$ & $\boldsymbol{I}_{\boldsymbol{c l}} \mathbf{1 9 5 8}$ & $\mathbf{2 0 1 7}{ }^{\circ} \mathbf{C}$ & $\boldsymbol{I}_{\boldsymbol{c l}} \mathbf{2 0 1 7}$ & $\mathbf{2 1 0 0}{ }^{\circ} \mathbf{C}$ & $\boldsymbol{I}_{\boldsymbol{c l}} \mathbf{2 1 0 0}$ \\
\hline January & 3.61 & 4.3 & 6.76 & 3.5 & 7.89 & 3.3 \\
\hline February & 4.12 & 4.0 & 8.96 & 3.1 & 9.94 & 3.0 \\
\hline March & 7.98 & 3.3 & 8.45 & 3.1 & 8.68 & 3.1 \\
\hline April & 15.03 & 2.1 & 17.82 & 1.6 & 18.46 & 1.5 \\
\hline May & 20.3 & 1.2 & 21.03 & 1.1 & 20.86 & 1.1 \\
\hline June & 24.3 & 0.6 & 26.57 & 0.3 & 26.7 & 0.2 \\
\hline July & 27.75 & 0.2 & 29.57 & 0 & 29.38 & 0 \\
\hline August & 28.2 & 0.1 & 28.04 & 0.1 & 27.86 & 0.05 \\
\hline September & 23.92 & 0.6 & 26.04 & 0.3 & 25.95 & 0.13 \\
\hline October & 18.26 & 1.6 & 22.22 & 1 & 22.37 & 1 \\
\hline November & 12.32 & 2.6 & 11.87 & 2.7 & 12.63 & 2.6 \\
\hline December & 6.51 & 3.5 & 5.86 & 3.9 & 6.2 & 3. \\
\hline Annual average & $\mathbf{1 6 . 0 3}$ & $\mathbf{2 . 0 1}$ & $\mathbf{1 7 . 7 7}$ & $\mathbf{1 . 7 3}$ & $\mathbf{1 8 . 0 8}$ & $\mathbf{1 . 5 8}$ \\
\hline Winter average (Oct-Mar) & $\mathbf{8 . 8 0}$ & $\mathbf{3 . 2 2}$ & $\mathbf{1 0 . 6 9}$ & $\mathbf{2 . 8 8}$ & $\mathbf{1 1 . 2 9}$ & $\mathbf{2 . 6 7}$ \\
\hline Summer average (Apr-Sep) & $\mathbf{2 3 . 2 5}$ & $\mathbf{0 . 8 0}$ & $\mathbf{2 4 . 8 5}$ & $\mathbf{0 . 5 7}$ & $\mathbf{2 4 . 8 7}$ & $\mathbf{0 . 5 0}$ \\
\hline
\end{tabular}

On the other hand, in Table 6, there is a comparison between the PMV index that the users would have if the indoor temperature would have been $20^{\circ} \mathrm{C}$ with the HVAC system OFF. The results of these simulations are the values of clothes thermal resistance $\left(I_{c l}\right)$, which shows how a user might be dressed for having this $P M V$ index in this environment.

Table 6. Clothes insulation in a $T=20{ }^{\circ} \mathrm{C}$ ambient with a $P M V$ index of the HVAC system OFF simulations.

\begin{tabular}{ccccccc}
\hline $\begin{array}{c}\text { Clothes Insulation } \\
\text { without HVAC System }\end{array}$ & PMV 1958 & $\mathbf{I}_{\boldsymbol{c l}} \mathbf{1 9 5 8}$ & $\mathbf{P M V ~ 2 0 1 7}$ & $\mathbf{I}_{\boldsymbol{c l}} \mathbf{2 0 1 7}$ & $\mathbf{P M V ~ I P C C}$ & $\boldsymbol{I}_{\boldsymbol{c l}} \mathbf{2 1 0 0}$ \\
\hline January & -2.35 & 0.10 & -1.82 & 0.50 & -1.52 & 0.70 \\
\hline February & -2.13 & 0.30 & -1.33 & 0.75 & -1.02 & 0.90 \\
\hline March & -1.43 & 0.70 & -1.16 & 0.90 & -0.84 & 1.00 \\
\hline April & -0.08 & 1.35 & 0.49 & 1.55 & 0.79 & 1.65 \\
\hline May & 1.26 & 1.80 & 1.51 & 1.90 & 1.81 & 2.00 \\
\hline June & 2.12 & 2.10 & 2.49 & 2.20 & 2.66 & 2.25 \\
\hline July & 2.79 & 2.30 & 3.00 & 2.40 & 3.00 & 2.40 \\
\hline August & 2.89 & 2.35 & 2.92 & 2.40 & 3.00 & 2.40 \\
\hline September & 2.28 & 2.15 & 2.57 & 2.25 & 2.82 & 2.35 \\
\hline October & 1.01 & 1.75 & 1.87 & 2.00 & 2.18 & 2.10 \\
\hline November & -0.28 & 1.15 & -0.34 & 1.15 & -0.03 & 1.35 \\
\hline December & -1.59 & 0.65 & -1.64 & 0.60 & -1.33 & 0.70 \\
\hline AVERAGE & $\mathbf{0 . 3 7}$ & $\mathbf{1 . 3 9}$ & $\mathbf{0 . 7 1}$ & $\mathbf{1 . 5 5}$ & $\mathbf{0 . 9 6}$ & $\mathbf{1 . 6 5}$ \\
\hline
\end{tabular}

\subsection{Thermo-Economics Evaluations Concerning Retrofit Process}

Simulation is credited with increasing efficiency and enabling the comparison of a broader range of design options, leading to a more balanced and optimized design. Simulations provide a better understanding of the consequences of design decisions, which are supposed to increase the overall building energy performance. The starting assumption of the study is that the building has to be renovated to meet a $15-20 \mathrm{kWh} / \mathrm{m}^{2}$ yearly energy demand threshold. Therefore, the renovation work costs, and the investment needed to support the process were analyzed and compared among the different solutions.

Table 7 shows the results of the simulations for each scenario. The current energy performance of the building is $155 \mathrm{kWh} / \mathrm{m}^{2}$ per year, which is a quite high level of energy demand considering the target. 
Table 7. Results of different scenarios.

\begin{tabular}{ccccc}
\hline Solution 2017 & Energy Consumption & Energy Savings & Energy Cost & Renovation Investment \\
\hline ACTUAL & $155 \mathrm{kWh} / \mathrm{m}^{2}$ & - & $88 \$ / \mathrm{m}^{2}$ & - \\
\hline Solution A & $94 \mathrm{kWh} / \mathrm{m}^{2}$ & $-40 \%$ & $86 \$ / \mathrm{m}^{2}$ & $1600 \$ / \mathrm{m}^{2}$ \\
\hline Solution B & $15 \mathrm{kWh} / \mathrm{m}^{2}$ & $-90 \%$ & $27 \$ / \mathrm{m}^{2}$ & $1800 \$ / \mathrm{m}^{2}$ \\
\hline Solution C & $13 \mathrm{kWh} / \mathrm{m}^{2}$ & $-91.5 \%$ & $26 \$ / \mathrm{m}^{2}$ & $2200 \$ / \mathrm{m}^{2}$ \\
\hline
\end{tabular}

Solution A-includes the replacement of windows and the introduction of an additional insulation layer in the inner side of the wall-lead the energy performance to $94 \mathrm{kWh} / \mathrm{m}^{2}$ per year, requiring a quite relevant investment for renovation.

Solution B-improves solution A and operates replacing the existing heating/cooling system with an electric heat pump and adding a controlled mechanic ventilation-reduces the energy demand to $15 \mathrm{kWh} / \mathrm{m}^{2}$ with about $90 \%$ of energy saving compared to the current status.

Solution C-improves solution B and simply adds the apartments refurbishment according to the HPD guidelines, achieving an overall energy performance of $13 \mathrm{kWh} / \mathrm{m}^{2}$ per year.

\section{Discussion}

\subsection{BEP of Current Conditions in Different Scenarios (1958, 2017 and 2100)}

Looking at the outcomes of the performed analyses of the three scenarios $(1958,2017,2100)$ is evident how loads, consumptions, and comfort are influenced by climate data. The research allowed to understand the variations correlated to outdoor/indoor temperature dealing with the building behavior (loads), the energy data (consumption), and the comfort data (PMV/PPD).

Comparing the situation between 1958 and 2100, reported in Figure 4, it can be noticed that there is an increase in the building's cooling needs of $50 \%$ in the 2100 prediction with respect to $2958(+14 \%$ in 2017 with respect to 1958), which clearly addresses the design challenge toward the summer period to find adequate technical answers for reducing the overheating effect. In 1958, energy demand for heating was $19 \%$, while in 2100 , it is expected to decrease to $12 \%$ (see Figure 4 ) with a consequent increase in the share for cooling, with a radical shift in the energy use and building thermal behavior compared with a conventional situation. Renovation works will reduce the energy demand for heating (fuel), replacing the existing boilers), but the request for electrical power will increase exponentially, impacting on the energy infrastructure. The increase of outdoor temperature will impact on indoor conditions and consequently on comfort condition for inhabitants and their related perception, which will be dependent on HVAC and installations.

\subsection{Thermal Comfort}

To understand how thermal comfort varies if HVAC is not operating, the users' perception was investigated with the purpose to better address the solutions dealing with the building envelope main features and performance. The increase in the share of energy demand for cooling is of particular interest at the European level where the use of the HVAC during the summer period is a quite recent need. Historic buildings are usually massive structure with natural ventilation and the wide building production between the 1960s and the 1980s was not originally air-conditioned. This represents a relevant cultural difference with the United States where the use of the HVAC is consolidated over a century. Figure 5 report a infographics about thermal comfort in each scenarios.

The choice to work on the NY case study reflects the will to work on a consolidated situation for both winter and summer energy demand regimes, assuming that the huge increase in the demand for cooling will represent a revolving trend in EU for the future.

The scientific literature provides a large production of studies about building thermal behavior and energy performance as well as about the retrofitting and renovation solution, however, the impacts of the projections in temperature trends reported by IPCC still represent an open field of research. 
The novelty of the proposed study lies in considering the interrelated factors focusing on the effects on thermal comfort perception by the users and on the potential deriving changes in life conditions and styles.

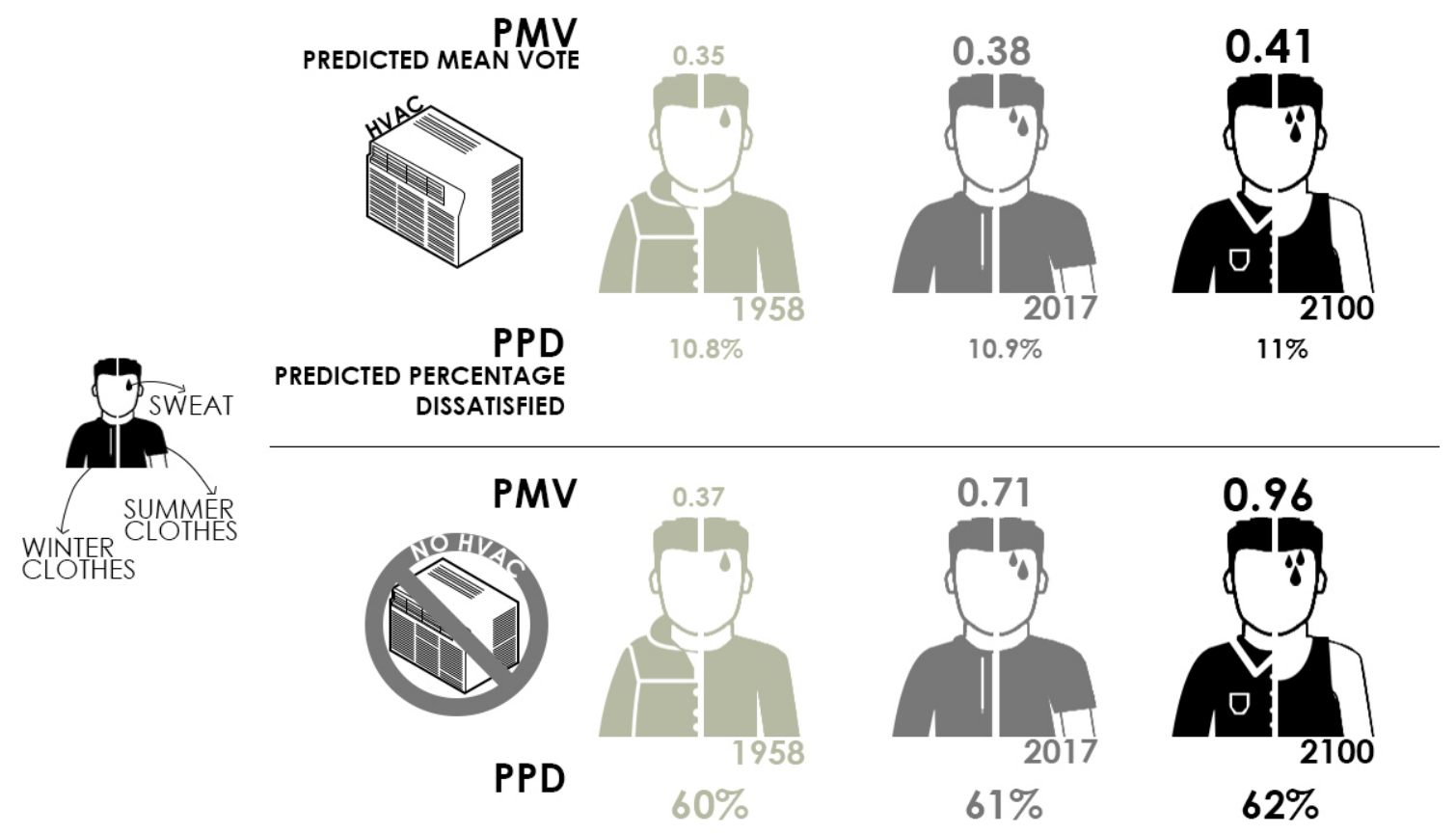

Figure 5. Infographic about thermal comfort in each scenario considering the HVAC system ON and OFF.

\subsection{Thermo-Economics Evaluations after Retrofitting for Improving Building Energy Performance}

Among the objectives of this study, there is the understanding of the impact of building renovation on heating/cooling demand with relation to the temperature increase projection. Three building renovation solutions were developed with relation to the 2017 scenario. Assuming the current status as the starting point, solution A replaces the existing windows with new ones, respecting the directives U-value $\left(\mathrm{W} / \mathrm{m}^{2} \mathrm{~K}\right)$ thresholds and adds a new insulation layer, achieving a savings of $40 \%$.

Solution B replaces the existing boiler for heating with an electrical heat pump for both heating and cooling, combined with a controlled mechanic ventilation, achieving a savings of $90 \%$. Solution C adds to $B$ the refurbishment of the apartments according HPD's guidelines.

The total energy performance shifts from $155 \mathrm{kWh} / \mathrm{m}^{2}$ (of the current status) to $13 \mathrm{kWh} / \mathrm{m}^{2}$ per year. The results are obtained modeling only the basic parameters involved such as insulation, window glazing and installations, but other key elements like the level of shading, building orientation, and window size, which were kept constant, can be varied to further improve the outcomes. The study assumed the limitation of preserving the exposed brick façade of the building, but in different context, a more performing insulation on the outer skin can be considered for improving the performances of the building envelope.

\section{Conclusions}

This research assumes that energy simulation and analysis must be carefully considered and included during the renovation process aimed at improving building energy performances, to achieve effective savings and more efficient design solutions in terms of comfort. The proposed methodology has, as the main objective, the replicability and can be helpful both in the case of renovation and in case of new construction, aiming to consider IPCC projections and the related effects on people's health and wellbeing. The method adopted also allows incremental numerical data to be obtained. This study evidences the risk of grid collapse and blackouts in case of demand peaks for cooling as 
it happened in NYC in July 1977 and more recently in July 2019, paralyzing the city for more than $3 \mathrm{~h}$. The main answer is, of course, to strengthen the energy infrastructure as the NYC authorities are already doing, however, a modal shift in approaching renovation and comfort evaluation could be of help in supporting a cultural change, which will be an unavoidable consequence of IPCC projections.

The outcomes of the case study confirm that climate change will significantly affect the future improvement of building energy performance and indoor thermal comfort (especially ventilation), becoming a global challenge that will require to work on thermal insulation and reflectance, but also on ventilation parameters that have a very relevant role on the demand for cooling.

That climate change and improvement of thermal and ventilation parameters significantly affect the demand for cooling - in time, it will be a huge global problem.

Further developments of the proposed study are certainly needed to explore the effects on different building typologies as well as on the inhabitant's reaction considering different climate contexts and cultural background.

Author Contributions: Conceptualization, K.F. and J.G.; methodology, K.F and J.G.; software, L.F.; validation, K.F., L.F. and J.G.; formal analysis, L.F.; investigation, L.F.; resources, J.G.; data curation, K.F.; writing-original draft preparation, L.F.; writing-review and editing, K.F. and J.G.; visualization, L.F.; supervision, K.F.; project administration, J.G.; funding acquisition, J.G. All authors have read and agreed to the published version of the manuscript.

Funding: This research received no external funding

Acknowledgments: In this section you can acknowledge any support given which is not covered by the author contribution or funding sections. This may include administrative and technical support, or donations in kind (e.g., materials used for experiments).

Conflicts of Interest: The authors declare no conflict of interest.

\section{Nomenclature}

\begin{tabular}{ll} 
AR5 & IPCC Fifth Assessment Report \\
BEP & Building Energy Performance \\
BEPS & Building Energy Performance Simulations \\
BPS & Building Performance Simulations \\
BLC & Building Life-Cycle \\
CC & Climate Change \\
EPBD & Energy Performance of Buildings Directive \\
EU & European Union \\
GHG & Greenhouse Gas \\
HPD & New York City Department of Housing Preservation and Development \\
HVAC & Heating, Ventilation and Air-Conditioning \\
IES.VE & Integrated Environment Virtual Environment software \\
IPCC & Intergovernmental Panel on Climate Change \\
NPCC & New York City Panel on Climate Change \\
NYCHA & New York City Housing Authority \\
nZEB & nearly Zero Energy Building \\
PMV & Predicted Mean Vote \\
PPD & Predicted Percentage Dissatisfied \\
RES & Renewable Energy Sources \\
RPS & Renewable Portfolio Standard \\
SB100 & California Senate Bill 100 \\
TMY & Typical Meteorological Year \\
UNFCCC & United Nations Framework Convention on Climate Change \\
& \\
\hline
\end{tabular}

\section{References}

1. Tol, R.S.J. Population and trends in the global mean temperature. Atmosfera 2017, 30, 121-135. [CrossRef] 
2. Ciscar, J.C.; Dowling, P. Integrated assessment of climate impacts and adaptation in the energy sector. Energy Econ. 2014, 46, 531-538. [CrossRef]

3. Schaeffer, R.; Szklo, A.S.; Pereira de Lucena, A.F.; Moreira Cesar Borba, B.S.; Pupo Nogueira, L.P.; Fleming, F.P.; Troccoli, A.; Harrison, M.; Boulahya, M.S. Energy sector vulnerability to climate change: A review. Energy 2012, 38, 1-12. [CrossRef]

4. Hilden, M.; Huuki, H.; Kivisaari, V.; Kopsakangas-Savolainen, M. The importance of transnational impacts of climate change in a power market. Energy Policy 2018, 115, 418-425. [CrossRef]

5. Pischke, E.C.; Solomon, B.; Wellstead, A.; Acevedo, A.; Eastmond, A.; De Oliveira, F.; Coelho, S.; Lucon, O. From Kyoto to Paris: Measuring renewable energy policy regimes in Argentina, Brazil, Canada, Mexico and the United States. Energy Res. Soc. Sci. 2019, 50, 82-91. [CrossRef]

6. Radhi, H. Evaluating the potential impact of global warming on the UAE residential buildings-A contribution to reduce the CO2 emissions. Build. Environ. 2009, 44, 2451-2462. [CrossRef]

7. Pérez-Andreu, V.; Aparicio-Fernández, C.; Martínez-Ibernón, A.; Vivancos, J.L. Impact of climate change on heating and cooling energy demand in a residential building in a Mediterranean climate. Energy 2018, 165, 63-74. [CrossRef]

8. Yamineva, Y. Lessons from the Intergovernmental Panel on Climate Change on inclusiveness across geographies and stakeholders. Environ. Sci. Policy 2017, 77, 244-251. [CrossRef]

9. IPCC. Summary for Policymakers. In Global Warming of $1.5^{\circ} \mathrm{C}$. An IPCC Special Report on the Impacts of Global Warming; IPCC: Geneva, Switzerland, 2018; ISBN 9789291691517.

10. Livingston, J.E.; Lövbrand, E.; Alkan-Olsson, J. From climates multiple to climate singular: Maintaining policy-relevance in the IPCC synthesis report. Environ. Sci. Policy 2018, 90, 83-90. [CrossRef]

11. Devès, M.H.; Lang, M.; Bourrelier, P.H.; Valérian, F. Why the IPCC should evolve in response to the UNFCCC bottom-up strategy adopted in Paris? An opinion from the French Association for Disaster Risk Reduction. Environ. Sci. Policy 2017, 78, 142-148. [CrossRef]

12. Zhai, Z.J.; Helman, J.M. Implications of climate changes to building energy and design. Sustain. Cities Soc. 2019, 44, 511-519. [CrossRef]

13. Flores-Larsen, S.; Filippín, C.; Barea, G. Impact of climate change on energy use and bioclimatic design of residential buildings in the 21st century in Argentina. Energy Build. 2019, 184, 216-229. [CrossRef]

14. Wang, H.; Chen, Q. Impact of climate change heating and cooling energy use in buildings in the United States. Energy Build. 2020, 82, 428-436. [CrossRef]

15. Shen, P. Impacts of climate change on U.S. building energy use by using downscaled hourly future weather data. Energy Build. 2017, 134, 61-70. [CrossRef]

16. Moazami, A.; Carlucci, S.; Nik, V.M.; Geving, S. Towards climate robust buildings: An innovative method for designing buildings with robust energy performance under climate change. Energy Build. 2019, 202, 109378. [CrossRef]

17. Augenbroe, G. Trends in building simulation. Build. Environ. 2002, 37, 891-902. [CrossRef]

18. Coakley, D.; Raftery, P.; Keane, M. A review of methods to match building energy simulation models to measured data. Renew. Sustain. Energy Rev. 2014, 37, 123-141. [CrossRef]

19. Attia, S.; Hamdy, M.; O’Brien, W.; Carlucci, S. Computational Optimisation for Zero Energy Buildings Design: Interviews Results with 28 International Experts. In Proceedings of the BS2013: 13th Conference of International Building Performance Simulation Association, Chambéry, France, 26-28 August 2013.

20. Gercek, M.; Durmuş Arsan, Z. Energy and environmental performance based decision support process for early design stages of residential buildings under climate change. Sustain. Cities Soc. 2019, 48, 101580. [CrossRef]

21. Council of the European Union. Energy and Climate Package-Elements of the Final Compromise Agreed by the European Council; Council of the European Union: Brussels, Belgium, 2008.

22. European Commission. A Policy Framwork for Climate and Energy in the Periodo from 2020 to 2030; European Commission: Brussels, Belgium, 2014.

23. European Commission. A Clean Planet for all A European Strategic Long-Term Vision for a Prosperous, Modern, Competitive and Climate Neutral Economy; European Commission: Brussels, Belgium, 2018.

24. Sánchez-garcía, D.; Rubio-bellido, C.; del Río, J.J.M.; Pérez-Fargallo, A. Towards the quantification of energy demand and consumption through the adaptive comfort approach in mixed mode office buildings considering climate change. Energy Build. 2019, 187, 173-185. [CrossRef] 
25. Campaniço, H.; Soares, P.M.M.; Cardoso, R.M.; Hollmuller, P. Impact of climate change on building cooling potential of direct ventilation and evaporative cooling: A high resolution view for the Iberian Peninsula. Energy Build. 2019, 192, 31-44. [CrossRef]

26. European Parliament. Directive 2010/31/EU of the European Parliament and of the Council of 19 May 2010 on the energy performance of buildings (recast). Off. J. Eur. Union 2010, L153, 13-35.

27. European Parliament. Directive 2018/844 amending Directive 2010/31/UE on the energy performance of building and Directive 2012/27/UE on energy efficiency ). Off. J. Eur. Union 2018, 2018, 75-91.

28. European Parliament. DIRECTIVE 2012/27/EU OF THE EUROPEAN PARLIAMENT AND OF THE COUNCIL of 25 October 2012 on energy efficiency, amending Directives 2009/125/EC and 2010/30/EU and repealing Directives 2004/8/EC. Off. J. Eur. Union 2012, L315, 1-56.

29. Andrić, I.; Pina, A.; Ferrão, P.; Fournier, J.; Lacarrière, B.; Le Corre, O. The impact of climate change on building heat demand in different climate types. Energy Build. 2017, 149, 225-234. [CrossRef]

30. Cellura, M.; Guarino, F.; Longo, S.; Tumminia, G. Energy for Sustainable Development Climate change and the building sector: Modelling and energy implications to an of fi ce building in southern Europe Special Report on Emissions Scenarios. Energy Sustain. Dev. 2020, 45, 46-65. [CrossRef]

31. Andrić, I.; Gomes, N.; Pina, A.; Ferrão, P.; Fournier, J.; Lacarrière, B.; Le Corre, O. Modeling the long-term effect of climate change on building heat demand: Case study on a district level. Energy Build. 2016, 126, 77-93. [CrossRef]

32. Thomas, K.A.; Warner, B.P. Weaponizing vulnerability to climate change. Glob. Environ. Chang. 2019, 57, 101928. [CrossRef]

33. Schulte, R.H.; Fletcher, F.C. 100\% Clean Energy: The California Conundrum. Electr. J. 2019, 32, 31-36. [CrossRef]

34. García Sánchez, F.; Solecki, W.D.; Ribalaygua Batalla, C. Climate change adaptation in Europe and the United States: A comparative approach to urban green spaces in Bilbao and New York City. Land Use Policy 2018, 79, 164-173. [CrossRef]

35. Energy; Planning New York 2015-State-Energy-Plan. 2015. Available online: https://energyplan.ny.gov/ Plans/2015.aspx (accessed on 16 June 2020).

36. New York State of Opportunity Reforming the Energy Vision (REV). 2016. Available online: https: //www.ny.gov/sites/ny.gov/files/atoms/files/WhitePaperREVMarch2016.pdf (accessed on 16 June 2020).

37. NYS Department of Public Service Reforming the Energy Vision. Reform. Energy Vis. $2014,85$. Available online: http://documents.dps.ny.gov/public/Common/ViewDoc.aspx?DocRefId=\%7B0B599D87445B-4197-9815-24C27623A6A0\%7D (accessed on 16 June 2020).

38. New York Academy of Sciences New York City Panel on Climate Change 2019 Report Executive Summary. Ann. N. Y. Acad. Sci. 2019, 1439, 11-21. [CrossRef] [PubMed]

39. Shen, P.; Braham, W.; Yi, Y. The feasibility and importance of considering climate change impacts in building retro fi t analysis Intergovernmental Panel on Climate Change. Appl. Energy 2019, 233-234, 254-270. [CrossRef]

40. Chan, A.L.S. Developing future hourly weather files for studying the impact of climate change on building energy performance in Hong Kong. Energy Build. 2011, 43, 2860-2868. [CrossRef]

41. Nik, V.M.; Sasic Kalagasidis, A. Impact study of the climate change on the energy performance of the building stock in Stockholm considering four climate uncertainties. Build. Environ. 2013, 60, 291-304. [CrossRef]

42. IES Virtual Environment Module Tutorial. 2019. Available online: https://www.iesve.com/ (accessed on 16 June 2020).

43. Roshan, G.; Oji, R.; Attia, S. Projecting the impact of climate change on design recommendations for residential buildings in Iran. Build. Environ. 2019, 155, 283-297. [CrossRef]

44. Farah, S.; Whaley, D.; Saman, W.; Boland, J. Integrating climate change into meteorological weather data for building energy simulation. Energy Build. 2019, 183, 749-760. [CrossRef]

45. Karimpour, M.; Belusko, M.; Xing, K.; Boland, J.; Bruno, F. Impact of climate change on the design of energy efficient residential building envelopes. Energy Build. 2015, 87, 142-154. [CrossRef]

46. Wang, L.; Liu, X.; Brown, H. Prediction of the impacts of climate change on energy consumption for a medium-size office building with two climate models. Energy Build. 2020, 157, 218-226. [CrossRef]

47. Fanger, P.O. Thermal Comfort. Analysis and Applications in Environmental Engineering; McGraw-Hill: New York, NY, USA, 1970; ISBN 9780070199156. 
48. ISO. ISO 7730 Ergonomics of the Thermal Environment-Analytical Determination and Interpretation of Thermal Comfort Using Calculation of the PMV and PPD Indices and Local Thermal Comfort Criteria; ISO: Geneva, Switzerland, 2005; Volume 2005.

49. ASHRAE 55, Thermal Environmental Conditions for Human Occupancy ASHRAE. 2010. Available online: https://www.ashrae.org/technical-resources/bookstore/standard-55-thermal-environmental-conditionsfor-human-occupancy (accessed on 16 June 2020).

50. Humphreys, M.A.; Fergus Nicol, J. The validity of ISO-PMV for predicting comfort votes in every-day thermal environments. Energy Build. 2002, 34, 667-684. [CrossRef]

51. Yang, Y.; Li, B.; Liu, H.; Tan, M.; Yao, R. A study of adaptive thermal comfort in a well-controlled climate chamber. Appl. Therm. Eng. 2015, 76, 283-291. [CrossRef]

52. Wang, L.; Kim, J.; Xiong, J.; Yin, H. Optimal clothing insulation in naturally ventilated buildings. Build. Environ. 2019, 154, 200-210. [CrossRef]

53. Liu, W.; Yang, D.; Shen, X.; Yang, P. Indoor clothing insulation and thermal history: A clothing model based on logistic function and running mean outdoor temperature. Build. Environ. 2018, 135, 142-152. [CrossRef]

54. De Carli, M.; Olesen, B.W.; Zarrella, A.; Zecchin, R. People's clothing behaviour according to external weather and indoor environment. Build. Environ. 2007, 42, 3965-3973. [CrossRef]

55. Sangi, R.; Martín, P.M.; Müller, D. Thermoeconomic analysis of a building heating system. Energy 2016, 111, 351-363. [CrossRef]

56. Bader, D.; Tryhorn, L.; Degaetano, A.; Rosenzweig, C. Climate Risks. In New York State Energy Research and Development, Responding to Climate Change in New York State (ClimAID); New York State Energy Research and Development Authority: New York, NY, USA, 2014; pp. 15-48. Available online: https://www.nyserda.ny. gov/-/media/Files/Publications/Research/Environmental/EMEP/climaid/ClimAID-Report.pdf (accessed on 16 June 2020).

57. ISO. ISO 9920-Ergonomics of the Thermal Environment-Estimation of Thermal Insulation and Water Vapour Resistance of a Clothing Ensemble; ISO: Geneva, Switzerland, 2008; Volume 2008.

(C) 2020 by the authors. Licensee MDPI, Basel, Switzerland. This article is an open access article distributed under the terms and conditions of the Creative Commons Attribution (CC BY) license (http://creativecommons.org/licenses/by/4.0/). 